ARTICLE

https://doi.org/10.1038/s41467-020-14302-3

\title{
No detectable Weddell Sea Antarctic Bottom Water export during the Last and Penultimate Glacial Maximum
}

Huang Huang (10 ${ }^{1 \star}$, Marcus Gutjahr (1) ${ }^{1}$, Anton Eisenhauer (10 ${ }^{1} \&$ Gerhard Kuhn (1) ${ }^{2}$

Weddell Sea-derived Antarctic Bottom Water (AABW) is one of the most important deep water masses in the Southern Hemisphere occupying large portions of the deep Southern Ocean (SO) today. While substantial changes in SO-overturning circulation were previously suggested, the state of Weddell Sea AABW export during glacial climates remains poorly understood. Here we report seawater-derived $\mathrm{Nd}$ and $\mathrm{Pb}$ isotope records that provide evidence for the absence of Weddell Sea-derived AABW in the Atlantic sector of the SO during the last two glacial maxima. Increasing delivery of Antarctic $\mathrm{Pb}$ to regions outside the Weddell Sea traced SO frontal displacements during both glacial terminations. The export of Weddell Sea-derived AABW resumed late during glacial terminations, coinciding with the last major atmospheric $\mathrm{CO}_{2}$ rise in the transition to the Holocene and the Eemian. Our new records lend strong support for a previously inferred AABW overturning stagnation event during the peak Eemian interglacial. 
T he Southern Ocean (SO) has long been identified as the key driver in regulating atmospheric $\mathrm{CO}_{2}$ concentrations on glacial-interglacial timescales, mediating oceanatmosphere carbon dioxide exchange by the interaction of variable export production ${ }^{1}$ and circulation changes ${ }^{2-5}$. Dissolved inorganic carbon (DIC)-enriched deep waters were increasingly upwelled to the SO surface during glacial terminations, where this DIC is degassed to the atmosphere as $\mathrm{CO}_{2}$. During the last deglaciation ( 18-11 ka BP), atmospheric $\mathrm{pCO}_{2}$ increased during two main intervals between $18-15 \mathrm{ka}$ and $13-11 \mathrm{ka}^{6}$, which occurred during Southern Hemispheric warming phases ${ }^{7}$. The multi-millennial-scale deglacial atmospheric $\mathrm{pCO}_{2}$ rise was largely a consequence of a southward-moving SO-overturning cell $^{2,8-10}$ and the associated increased upwelling in the Southern Ocean. At least three intervals of centennial-scale atmospheric $\mathrm{pCO}_{2}$ rise were reported during Termination I (at 16.3, 14.8, and $11.7 \mathrm{ka}$ ) that can be linked to Northern Hemispheric climate transitions, likely controlled by AMOC reinvigoration and the associated climatic teleconnections ${ }^{11}$.

In contrast to the state of knowledge regarding the understanding of deglacial frontal shifts and increasing deep SO overturning, strikingly little is known with respect to changes in water mass sourcing before and during glacial terminations. For example, while deep SO water masses at the end of the Last Glacial Maximum (LGM) were identified as being depleted in both $\delta^{13} \mathrm{C}^{12}$ and radiocarbon ${ }^{3,5}$ alongside relatively low dissolved oxygen concentrations ${ }^{4}$, the geographic origin of this glacial deep $\mathrm{SO}$ water mass is unresolved to date. This situation is dissatisfactory since commonly termed Southern Source Waters (SSW) have been invoked to occupy large parts of the deeper Atlantic Ocean at the expense of North Atlantic Deep Water (NADW) during the Last Glacial Maximum and major Northern Hemisphere Stadials ${ }^{13,14}$, with consequences for deep ocean carbon sequestration ${ }^{15}$. No study could as yet unambiguously demonstrate that this postulated SSW is the glacial equivalent of interglacial Antarctic Bottom Water or whether SSW originated from other abyssal parts of the world's oceans.

Weddell Sea-derived AABW is formed at several locations on the Antarctic shelf today, most prominently in front of the Filchner, Ronne, and Larsen ice shelfs in the southern and western Weddell Sea ${ }^{16,17}$. Weddell Sea Bottom Water is the coldest and densest variety of Antarctic Bottom Water formed within the Weddell Sea ${ }^{18}$. It mixes with the overlying Weddell Sea Deep Water and modified warm deep water that is advected into the Weddell Sea within the Weddell Gyre, eventually leaving the basin to the north and northeast as Weddell Sea Deep Water ${ }^{19-21}$, which we refer to as Weddell Sea-derived AABW below. Within the Scotia Sea, freshly exported Weddell Sea-derived AABW mixes with Lower Circumpolar Deep Water arriving from the Pacific sector of the SO before its advection to our sediment core sites in the Atlantic sector of the $\mathrm{SO}^{22}$.

We address the issue of SO water mass sourcing by using two sensitive provenance proxies, the authigenic $\mathrm{Fe}-\mathrm{Mn}$ oxyhydroxide-bound neodymium $(\mathrm{Nd})$ and lead $(\mathrm{Pb})$ isotope signatures in deep SO sediments. Both trace metals are supplied to the oceans mainly from continental runoff or dust input ${ }^{23}$. Yet while $\mathrm{Nd}$ is also supplied via porewater exchange processes along continental margins ${ }^{24}$, such an input mechanism has as yet not been reported for $\mathrm{Pb}$. Both proxies carry the isotopic composition of their continental source area and subsequent alteration through water mass mixing along their flow path. Since $\mathrm{Pb}$ is more particle-reactive than $\mathrm{Nd}$, its residence time in seawater is significantly shorter on the order of few tens of years ${ }^{25}$, compared with several hundreds of years for dissolved $\mathrm{Nd}^{26}$. The high particle reactivity of $\mathrm{Pb}$ also leads to its special behavior in seawater in contrast to $\mathrm{Nd}$. A recent study ${ }^{27}$ demonstrated that even without vertical water mass mixing, temporally changing $\mathrm{Pb}$ isotopic compositions in North Pacific surface water left a footprint in the underlying deep-water $\mathrm{Pb}$ isotope signal through seawater-particle exchange by sinking particles. Consequently, the seawater-derived authigenic $\mathrm{Pb}$ isotope signature in deep marine sediments in the Southern Ocean can be controlled both by changes in the upper and lower overturning cells. In contrast to authigenic $\mathrm{Pb}$, the $\mathrm{Nd}$ isotope signal of the same deep marine authigenic $\mathrm{Fe}-\mathrm{Mn}$ oxyhydroxide fraction only records bottom or porewater compositions ${ }^{28,29}$. Taking advantage of the different behavior of $\mathrm{Pb}$ and $\mathrm{Nd}$ in seawater, past seawater $\mathrm{Pb}$ isotopic compositions extracted from the authigenic Fe-Mn oxyhydroxide fraction in deep marine sediments ${ }^{30}$ hence provide insights into isotopic changes of the entire water column, while the $\mathrm{Nd}$ isotopic composition extracted from deep marine sediments is controlled by bottom water conditions.

Our records resolve changes in the upper and lower SOoverturning cells ${ }^{18,31}$ across the two most recent glacial-interglacial transitions (Termination I, TI and Termination II, TII). We provide evidence for the absence of AABW export from the Weddell Sea during the last and penultimate glacial maximum into the Atlantic sector of the SO. While the deglacial southward migration of the $\mathrm{SO}$ fronts is clearly resolvable in the $\mathrm{Pb}$ isotopic record, the $\mathrm{Nd}$ isotope data suggest that export of Weddell Sea-derived AABW resumed late during both glacial terminations, coinciding with the last major atmospheric $\mathrm{CO}_{2}$ rise in the transition to the Holocene and the Eemian. Overall our data suggest that Weddell Sea AABW export can be reduced or absent during both colder and warmer climates than current.

\section{Results}

Sediment core sites. We generated seawater $\mathrm{Pb}$ isotope records $\left({ }^{206} \mathrm{~Pb} / 204 \mathrm{~Pb}\right.$ and $\left.{ }^{208} \mathrm{~Pb} / 204 \mathrm{~Pb}\right)$ from a sediment core in the Atlantic sector of the SO (ODP Leg 177, Site $1094,53.2^{\circ} \mathrm{S}, 5.1^{\circ} \mathrm{E}$, water depth $2807 \mathrm{~m}$; Fig. 1), and the corresponding bottom water $\mathrm{Nd}$ isotope records $\left({ }^{143} \mathrm{Nd} /{ }^{144} \mathrm{Nd}\right.$, expressed as $\left.\varepsilon_{\mathrm{Nd}}\right)$ from authigenic $\mathrm{Fe}-\mathrm{Mn}$ oxyhydroxides of two additional sediment cores: one located very close to ODP Site 1094 (PS1768-8, 53.6 ${ }^{\circ} \mathrm{S}, 4.5^{\circ} \mathrm{E}$, water depth $3299 \mathrm{~m}$ ) and another located on the northern continental slope of the Antarctic Filchner-Rønne Ice Shelf (PS1599$3,74.1^{\circ} \mathrm{S}, 27.7^{\circ} \mathrm{W}$, water depth $2487 \mathrm{~m}$; Fig. 1). The two northern sites are ideally located to sensitively record past changes in SO circulation due to their position in the mixing zone between Circumpolar Deep Water (CDW) and Weddell Sea Deep Water (WSDW) (Fig. 1) ${ }^{18,21}$. Specifically, at ODP Site 1094 and PS17688 , covariation of $\mathrm{Pb}$ and $\mathrm{Nd}$ isotopic trends dominantly traces variations in the lower overturning cell, while $\mathrm{Pb}$ isotopic changes that have no resemblance in the $\mathrm{Nd}$ isotopic record reveal processes within the upper overturning cell. At the same time, the southern core from the East Antarctic margin enables us to monitor the $\varepsilon_{\mathrm{Nd}}$ water mass signature of cold dense shelf water mixing with ambient water masses on the continental slope to the north of the Filchner-Rønne Ice Shelf ${ }^{18}$.

$\mathrm{Pb}$ isotopic evolution during Termination I. Least radiogenic (lowest) $\mathrm{Pb}$ isotope compositions at ODP Site 1094 were recorded during the Last Glacial Maximum (Fig. 2b, c). Both ${ }^{206} \mathrm{~Pb} /{ }^{204} \mathrm{~Pb}$ and ${ }^{208} \mathrm{~Pb} / 204 \mathrm{~Pb}$ experienced a major change to significantly more radiogenic $\mathrm{Pb}$ isotopic compositions during the early deglaciation until the onset of the Antarctic Cold Reversal ( $~ 15 \mathrm{ka}$ BP) during which the ambient $\varepsilon_{\mathrm{Nd}}$ at Site PS1768-8 was invariant (Fig. 2g), suggesting changes in the upper SO-overturning cell only. The change in $\mathrm{Pb}$ isotope composition during this interval is very steady over more than $3 \mathrm{ka}$. It coincides with the first rise in atmospheric $\mathrm{pCO}_{2}$ (Fig. 2a) and correlates with indicators of 


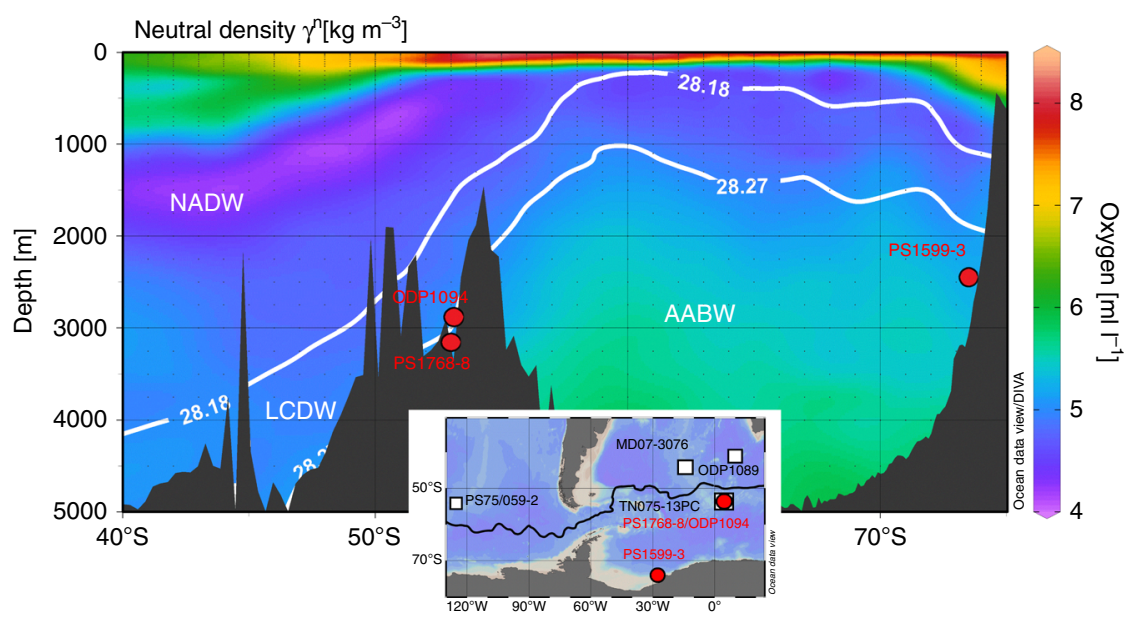

Fig. 1 Studied sediment core sites. Color-mapped oxygen concentrations, with neutral density contours $\left(\gamma^{n}\right)$ overlain, as drawn from the 2013 World Ocean Atlas 69,70 . Sediment cores presented here (ODP Site 1094, PS1768-8 and PS1599-3) are marked with red circles. The locations of other cores mentioned in the text are marked as white squares in the inlet map. The isopycnal with a neutral density of $28.27 \mathrm{~kg} \mathrm{~m}^{-3}$ defines the water mass boundary between AABW and LCDW, while the $28.18 \mathrm{~kg} \mathrm{~m}^{-3}$ isopycnal defines the top of Antarctic Circumpolar Current bottom water as defined in Orsi et al. ${ }^{18}$. Figure created with Ocean Data View ${ }^{71}$. AABW: Antarctic Bottom Water; LCDW: Lower Circumpolar Deep Water; NADW: North Atlantic Deep Water.

increasing upwelling in the Atlantic sector of the SO (i.e., a decrease in deep SO radiocarbon reservoir ages ${ }^{5}$ (Fig. 2d), and increasing opal flux ${ }^{2}$ (Fig. 2e)). In ${ }^{206} \mathrm{~Pb} /{ }^{204} \mathrm{~Pb}-{ }^{208} \mathrm{~Pb} /{ }^{206} \mathrm{~Pb}$ isotope space (Fig. 3), the isotopic signature during the glacial interval of our records resembles most closely hydrogenetic $\mathrm{Pb}$ isotope compositions seen at the Drake Passage and the SW Atlantic, trending toward eastern Weddell Sea compositions throughout the deglaciation. We can exclude a dust, anthropogenic or IRD control on the observed $\mathrm{Pb}$ isotopic changes (see Supplementary Figs. 3, 5, and 6). The steadiness of the $\mathrm{Pb}$ isotopic shift (Fig. 2b, c) during the early deglaciation argues for a gradual oceanic process on millennial timescales, and we interpret these changes as corresponding to a gradual southward displacement of major oceanic fronts in the SO during the first half of Termination I until the Antarctic Cold Reversal (ACR) ${ }^{10}$ (Fig. 2b, c).

$\varepsilon_{\mathrm{Nd}}$ variation during Termination I. In context of the early deglacial $\mathrm{Pb}$ isotopic evolution of the $\mathrm{SO}$ water column, a key observation in our records can be made in the bottom water $\mathrm{Nd}$ isotopic record of Site PS1768-8. The $\varepsilon_{\mathrm{Nd}}$ seen during the late LGM and most parts of the deglaciation until $12.7 \mathrm{ka} \mathrm{BP}$ is on the order of $\sim-4$ (Fig. 2g). Such a composition is uncommon for the Atlantic sector of the SO that features a modern composition of $-8.5 \pm 0.39 \varepsilon_{\mathrm{Nd}}{ }^{32}$, implying entirely different water mass sourcing and circulation regime during glacial climate compared with the present-day situation. The $\varepsilon_{\mathrm{Nd}}$ remained very radiogenic until late into the deglaciation, when it changed to compositions close to modern Lower Circumpolar Deep Water (LCDW) $\varepsilon_{\mathrm{Nd}}$ within about 2000 years. The clearly defined change in $\varepsilon_{\mathrm{Nd}}$ was associated with a second smaller excursion toward more radiogenic $\mathrm{Pb}$ isotopic compositions (Fig. 2b, c), an increase in East Antarctic ice core EDML $\delta^{18} \mathrm{O}^{33}$ (Fig. 2j), and the second rise in atmospheric $\mathrm{pCO}_{2}$ (Fig. 2a), and coincided with increasing Ross Sea AABW export in the Pacific sector of the $\mathrm{SO}^{34}$ (Fig. $2 \mathrm{~h}$ ).

\section{Discussion}

The glacial deep-water $\mathrm{Pb}$ isotopic composition (25 ka-18 ka) agrees with water mass sourcing from the Drake Passage and the SW Atlantic (Fig. 3). The contemporaneous very radiogenic $\varepsilon_{\mathrm{Nd}}$ in PS1768-8 was clearly different from Nd isotope compositions recorded within the Weddell Sea at Site PS1599-3 at the end of the LGM (19 ka-18 ka) (Fig. 2g). Active export of AABW during the late LGM from the Weddell Sea should transfer Weddell Sea $\mathrm{Pb}$ and $\mathrm{Nd}$ isotope signatures to our two northern SO sites, yet such a signal is not observed. Our results therefore suggest the absence of Weddell Sea-derived AABW export to the Atlantic sector of the SO during the LGM (illustrated in Fig. 4a). As indicated above, onset or invigoration of AABW export should result in simultaneous changes in our $\mathrm{Pb}$ and $\mathrm{Nd}$ isotope records. In contrast, the $\varepsilon_{\mathrm{Nd}}$ in PS1768-8 remained constant and radiogenic until $13 \mathrm{ka}$, while only $\mathrm{Pb}$ isotope composition attained eastern Weddell Sea signatures already before the onset of the ACR (Fig. 2b, c). Since the deep marine Pb isotope signal is influenced by changes in the entire water column, but the deep $\mathrm{Nd}$ isotope signature only responds to transitions in bottom water sourcing, we suggest that the decoupled $\mathrm{Pb}$ isotope evolution between 18 and $13 \mathrm{ka}$ was merely controlled by circulation changes in the upper water column without significant Weddell Sea-derived AABW export. Given the strikingly steady increase in ${ }^{206} \mathrm{~Pb} / 204 \mathrm{~Pb}$ and ${ }^{208} \mathrm{~Pb} /{ }^{204} \mathrm{~Pb}$ during the early deglacial until $\sim 14.7 \mathrm{ka}$ at ODP Site 1094, its covariation with atmospheric $\mathrm{pCO}_{2}$ (Fig. 2a), and correlation with other proxies indicative for increasing upwelling during this interval (Fig. 2d, e), we regard the steady $\mathrm{Pb}$ isotopic shift as tracing the southward displacement of the SO fronts, resulting in increasing admixtures of Weddell Sea-sourced near-surface waters (illustrated in Fig. 4b). This interpretation is further supported by water column $\delta^{18} \mathrm{O}$ and $\delta^{13} \mathrm{C}$ reconstructions of the Atlantic sector of the SO that recorded water column isotopic changes only in water depths shallower than $\sim 2.5 \mathrm{~km}$ during the early deglacial ${ }^{35}$. We also note that the $\mathrm{Pb}$ isotope records define a plateau during the early ACR, which corresponds to the timing of Meltwater Pulse 1A (MWP1a). A high-resolution iceberg-rafted debris record from the Scotia Sea identified this time interval as the most prominent ice-rafting event from the Weddell Sea during $\mathrm{TI}^{36}$. A recent modeling study furthermore suggested increased meltwater rates in the Weddell Sea sector of the Southern Ocean after Heinrich Stadial 1, which may have temporarily affected overturning strength in the $\mathrm{SO}^{37}$. The $\mathrm{Pb}$ isotope evolution at ODP Site 1094 throughout the ACR agrees with such a scenario.

The Nd isotope record from Site PS1768-8 in turn contains key information on abyssal overturning dynamics in the lower SO circulation cell. Generally, Nd isotopic changes in South Atlantic settings are usually more gradual ${ }^{38}$, while $\varepsilon_{\mathrm{Nd}}$ changes, such as 


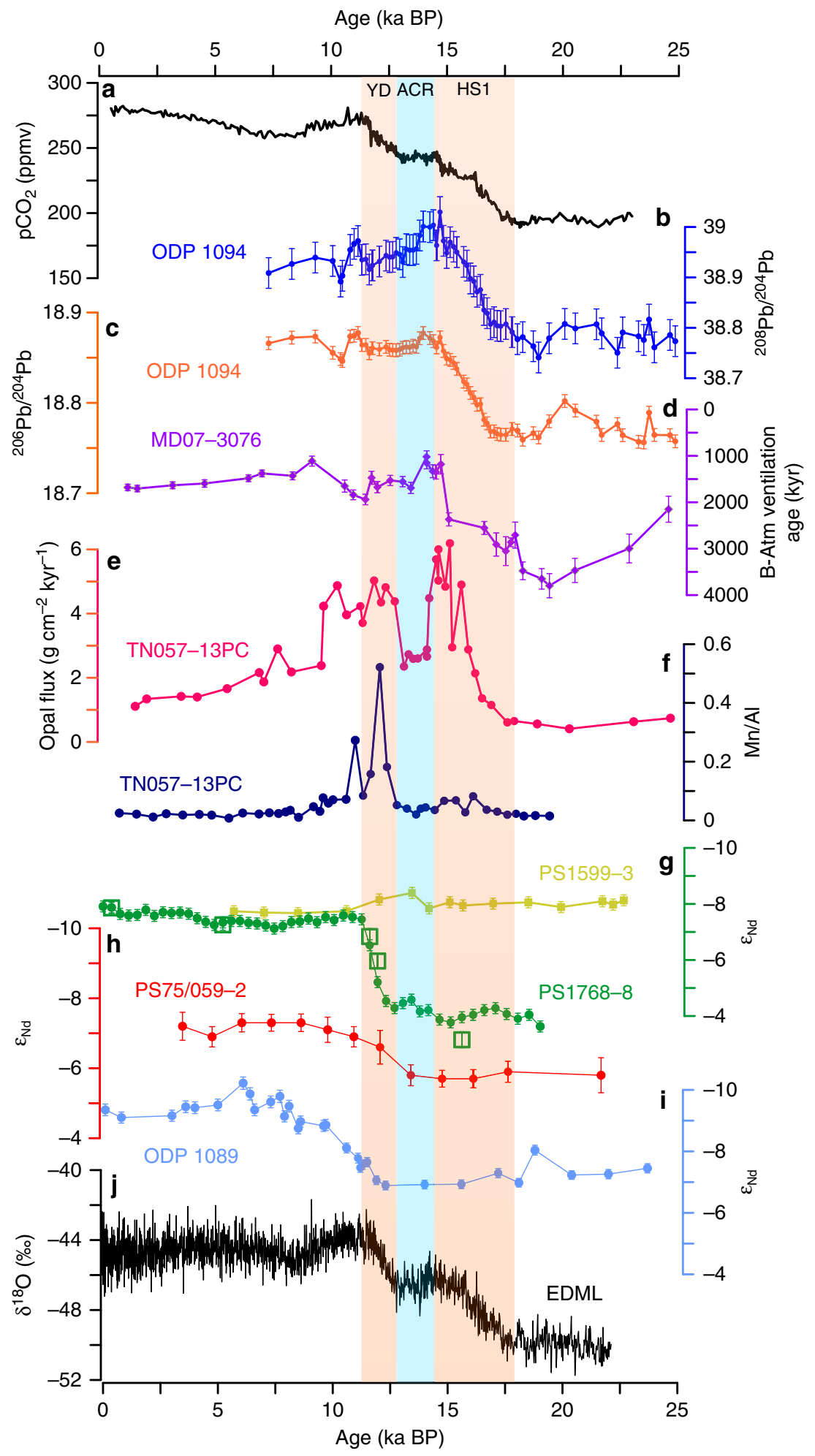

Fig. 2 Paleoclimatic reconstructions over the past $\mathbf{2 5 , 0 0 0}$ years. a Atmospheric $\mathrm{pCO}_{2}$ concentrations from Antarctic Dome $\mathrm{C}$ ice core ${ }^{6}$ and the West Antarctic Ice Sheet Divide ice core (WDC) ${ }^{11}$. b, c Authigenic Fe-Mn oxyhydroxide-based ${ }^{206} \mathrm{~Pb} /{ }^{204} \mathrm{~Pb}$ and ${ }^{208} \mathrm{~Pb} /{ }^{204} \mathrm{~Pb}$ records from ODP Site 1094. d Benthic-atmospheric (B-Atm) ventilation age ${ }^{5}$. e ${ }^{230}$ Th-normalized biogenic opal flux ${ }^{2}$. f TN057-13PC sedimentary $\mathrm{Mn}_{\mathrm{AI}}{ }^{4}$. $\mathbf{g} \boldsymbol{\varepsilon}_{\mathrm{Nd}} \mathrm{records}$ extracted from bulk sediment from PS1599-3 (yellow-green circles) and PS1768-8 (darker green circles) and opal from PS1768-8 (open green squares). $\mathbf{h}$ Fish teeth and planktic foraminifera $\varepsilon_{N d}$ of South Pacific core PS75/059-234. i $\varepsilon_{N d}$ records extracted from ODP Site $1089^{39}$. $\mathbf{j}$ EDML ice core $\delta^{18} \mathrm{O}^{33}$. Error bars correspond to the $2 \sigma$ external error of the ${ }^{206} \mathrm{~Pb} /{ }^{204} \mathrm{~Pb},{ }^{208} \mathrm{~Pb} /{ }^{204} \mathrm{~Pb}$, and $\varepsilon_{\mathrm{Nd}}$ measurements. The orange and blue boxes indicate periods of strong and diminished deglacial $\mathrm{CO}_{2}$ rise. YD: Younger Dryas; ACR: Antarctic Cold Reversal; HS1: Heinrich Stadial 1. 

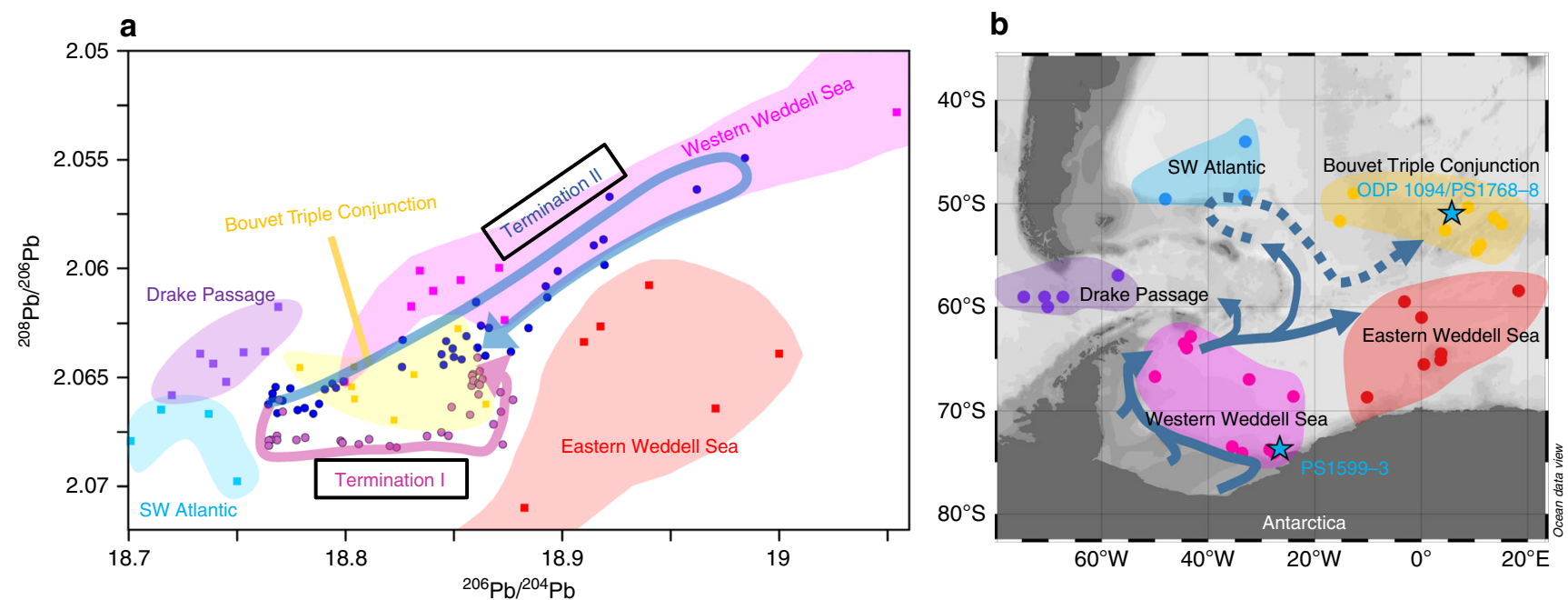

Fig. $3{ }^{206} \mathrm{~Pb} /{ }^{204} \mathrm{~Pb}-{ }^{208} \mathrm{~Pb} /{ }^{206} \mathrm{~Pb}$ trends during Terminations I and II. a Authigenic Fe-Mn oxyhydroxide-based Pb isotopic evolution observed at Site 1094 compared with $\mathrm{Pb}$ isotopic signatures in surface $\mathrm{Fe}-\mathrm{Mn}$ nodules ${ }^{72}$ and compositions extracted from core-top sediment samples in different parts of the Atlantic sector of the Southern Ocean shown in (b) (see the section "Methods"). The regionally characteristic Pb isotopic signature for various regions is marked by different colors. The arrows delineate the $\mathrm{Pb}$ isotopic evolution across the last two glacial-interglacial transitions (Termination I arrow covers $18 \mathrm{ka}-12 \mathrm{ka}$ BP and Termination II arrow covers $142 \mathrm{ka}-125 \mathrm{ka}$ BP). b Locations of Fe-Mn nodules and core-top sediment samples (Supplementary Data 2). The blue arrows in (b) indicate the modern AABW circulation and export path. The dashed blue arrow traces the LCDW flow path after entrainment of Weddell Sea AABW ${ }^{73}$. Panel (b) created with Ocean Data View ${ }^{71}$. AABW: Antarctic Bottom Water; LCDW: Lower Circumpolar Deep Water.

those seen at $\sim 13$ ka here, are commonly observed in the deglacial North Atlantic ${ }^{39}$. The rapidity and magnitude of change in $\varepsilon_{\mathrm{Nd}}$ together with synchronous ${ }^{206} \mathrm{~Pb} / 204 \mathrm{~Pb}$ and ${ }^{208} \mathrm{~Pb} /{ }^{204} \mathrm{~Pb}$ excursions hence argues for a local bottom water mass sourcing switch. While $\delta^{18} \mathrm{O}$ and $\delta^{13} \mathrm{C}$ water column properties below $\sim 2.5-\mathrm{km}$ water depth in the Atlantic sector of the SO did not change substantially before the late deglacial, a clear shift toward Holocene values was reported during this time window ${ }^{35}$. Given the water mass provenance information contained in the $\mathrm{Nd}$ and $\mathrm{Pb}$ isotope proxies, we can identify the transition to typical Weddell Sea $\varepsilon_{\mathrm{Nd}}$ signatures that covaried with these deep ocean $\delta^{18} \mathrm{O}$ and $\delta^{13} \mathrm{C}$ changes as recording the onset of Weddell Sea Deep Water export into northern reaches of the $\mathrm{SO}$ at $\sim 13 \mathrm{ka} \mathrm{BP}$ (illustrated in Fig. 4c). ODP Site 1089 located to the NE of Site PS1768-8 recorded simultaneous changes in $\varepsilon_{\mathrm{Nd}}$ alongside our site (Fig. 2i). Yet at Site 1089 this switch is more gradual and offset to less radiogenic $\varepsilon_{\mathrm{Nd}}$, reflecting its position further away from the exit route of Weddell Sea AABW, and also being located in the export path of NADW into the $\mathrm{SO}^{38,39}$. In contrast to Site PS1768-8, the southernmost $\varepsilon_{\mathrm{Nd}}$ record from Site PS1599-3 (Fig. 2g) situated on the East Antarctic continental rise that continuously monitored Weddell Sea compositions is strikingly invariant over Termination I and converged with northern Site PS1768-8 at this time. Last but not least, a further study reported a sedimentary $\mathrm{Mn} / \mathrm{Al}$ spike (Fig. 2f) in the nearby core TN057-13PC of PS1768-84, interpreted as being driven by an increased ventilation of AABW during this interval.

The absence of Weddell Sea AABW export into the northern reaches of the SO outside the Weddell Sea during glacial climates has not been reported to date. In prior studies a sluggish yet operational glacial AABW water mass presence in the SO was invoked in glacial circulation scenarios ${ }^{10,40-42}$, although no study to date could localize the origin of this deep glacial SO water mass. We tested the integrity of our presented Nd isotope signal by extracting the pure opal fraction from the same sediments without adhering terrigenous material and gently extracted the authigenic signature from these. The $\varepsilon_{\mathrm{Nd}}$ extracted from these opal samples is matching the bulk sediment leach results (Fig. $2 \mathrm{~g}$ ). The authigenic signal is also different from detrital $\varepsilon_{\mathrm{Nd}}$ signatures in the Holocene and late deglacial section of this core (Supplementary Fig. 1). Moreover, the $\varepsilon_{\mathrm{Nd}}$ record appears very clear-cut, suggesting two water mass circulation regimes. We have hence good reason to suggest that the water mass change observed in our record at $13 \mathrm{ka} \mathrm{BP}$ is not controlled by analytical artifacts.

However, a second key information contained in our $\varepsilon_{\mathrm{Nd}}$ record is the glacial deep-water composition with an $\varepsilon_{\mathrm{Nd}}$ of $\sim-4$. In the modern ocean such a composition is characteristic for North Pacific Deep Water (NPDW) ${ }^{43}$. Although NPDW contributes to LCDW today ${ }^{44}$, no resolvable isotopic trace of this $\varepsilon_{\mathrm{Nd}}$ signature can be found in the present-day Drake Passage water column $^{32}$ upstream from Site PS1768-8. Conversely, cold-water coral-based glacial and deglacial Upper Circumpolar Deep Water (UCDW) Nd isotope records presented from water depths between 700 and $1750 \mathrm{~m}$ suggest that $\varepsilon_{\mathrm{Nd}}$ within UCDW at the Drake Passage did not become more radiogenic than an $\varepsilon_{\mathrm{Nd}}$ of $\sim$ -6 at any time during Termination $\mathrm{I}^{45}$. A previous record from the South Atlantic (Site MD07-3076, 44 $4.46^{\prime} \mathrm{S}, 14^{\circ} 12.47^{\prime} \mathrm{W}$, 3770 -m depth) reported early deglacial $\varepsilon_{\mathrm{Nd}}$ of $\sim-5.5^{46}$. Potentially, $\mathrm{Nd}$ can be released from marine sediments to deep marine bottom water under very sluggish circulation regimes ${ }^{24,29}$. In marine settings such as the North Pacific ${ }^{28}$ or North Atlantic ${ }^{29}$, where this process has been observed, the porewater signature (i.e., the $\varepsilon_{\mathrm{Nd}}$ signal extracted here) is expected to be altered away from bottom water $\varepsilon_{\mathrm{Nd}}$ toward other non-hydrogenetic sedimentary phases such as volcanic debris within the sediment ${ }^{29}$. If the early deglacial South Atlantic and Drake Passage water column signatures on the order of $-5.5^{46}$ to $-6.0^{45}$ were equally representative for our core sites in the Atlantic sector of the SO, then the radiogenic glacial and deglacial signatures on the order of $\sim-4$ were affected by such porewater alteration, changing the authigenic $\varepsilon_{\mathrm{Nd}}$ to some degree away from ambient bottom water compositions. Hence if Weddell Sea-derived AABW had been advected to Site PS1768-8 in a very sluggish deep-water circulation regime during earlier parts of the deglaciation, we could have missed its arrival. We cannot entirely exclude this possibility although we consider it very unlikely since onset of a stronger bottom water circulation regime should equally result in authigenic $\varepsilon_{\mathrm{Nd}}$ that is closer to modern compositions. Whether the 

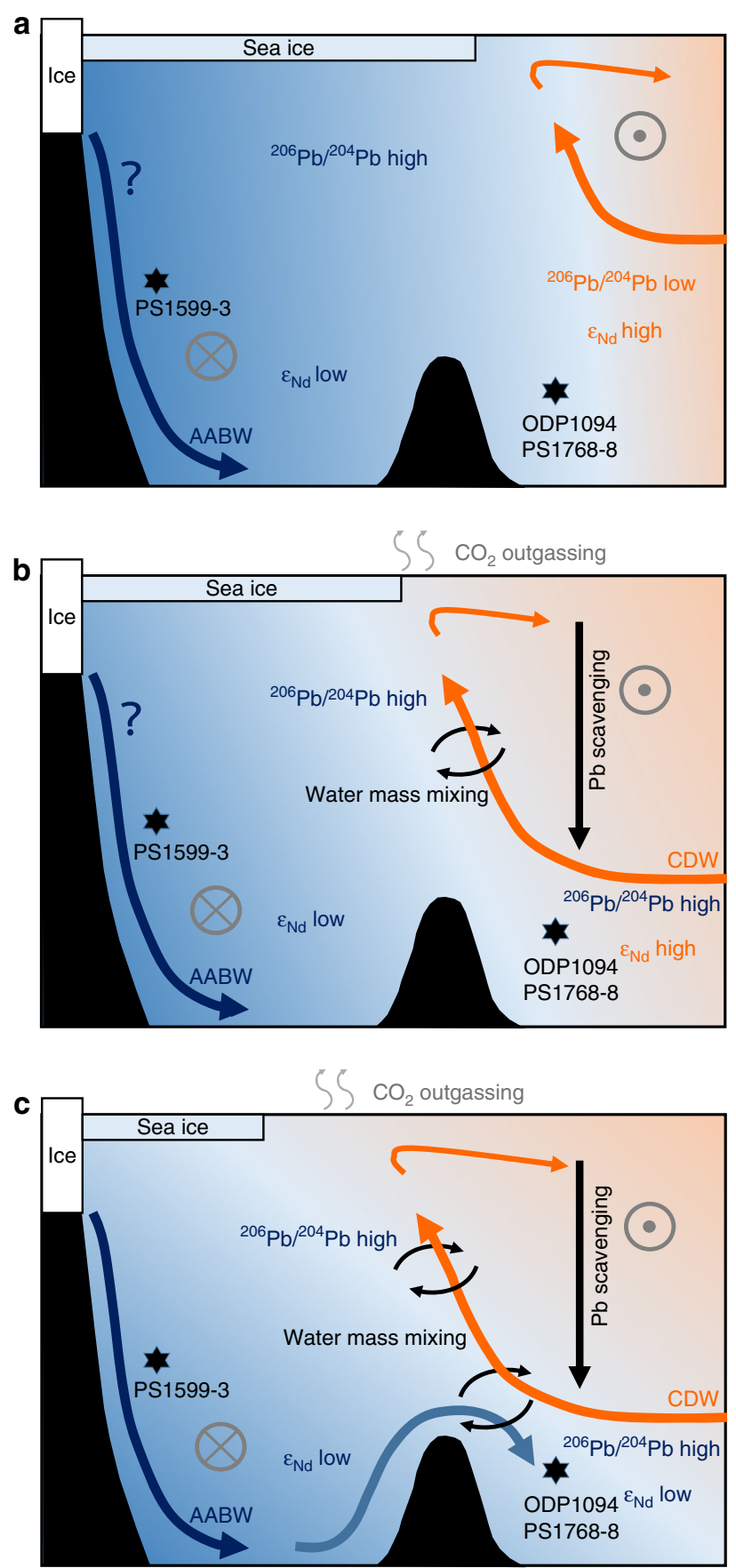

Fig. 4 Hypothesized Southern Ocean circulation modes. a LGMoverturning configuration with northward-shifted Southern Ocean circulation cell and absence of Weddell Sea-derived AABW at ODP Site 1094/Site PS1768-8, resulting in unradiogenic (low) ${ }^{206} \mathrm{~Pb} /{ }^{204} \mathrm{~Pb}$ and local radiogenic (high) $\varepsilon_{N d}$ signature. $\mathbf{b}$ Early deglacial overturning as experienced preceding the Antarctic Cold Reversal ( $15 \mathrm{ka}$ ). Southward displacement of Southern Ocean overturning cell, leading to entrainment of a Weddell Sea-sourced radiogenic (high) Pb isotope signal. c Post-Younger Dryas (YD) (since $11 \mathrm{ka}$ ) and Holocene overturning configuration. Reinvigoration of $A A B W$ export resulted in the convergence of $\varepsilon_{N d}$ inside and outside of the Weddell Sea. Crosses mark predominant westward flow directions and the point symbol denotes eastward flow. LGM: Last Glacial Maximum; AABW: Antarctic Bottom Water; CDW: Circumpolar Deep Water. deglacial deep-water $\varepsilon_{\mathrm{Nd}}$ was indeed affected by porewater alteration processes still needs to be confirmed. Since the modern extracted $\varepsilon_{\mathrm{Nd}}$ compositions at Site PS1768-8 agree with direct seawater data, such an alteration was limited to (de)glacial climate stages and significantly reduced SO overturning.

To test whether our observed changes are indeed controlled by Milankovitch cycles forcing we also investigated the $\mathrm{Pb}$ and $\mathrm{Nd}$ isotope evolution at the same sites during Termination II (Fig. 5). The temporal change in incoming solar radiation during TII was significantly larger than that seen during $\mathrm{TI}^{47}$, leading to monotonic warming over $\sim 8 \mathrm{ka}^{48}$, peak Eemian temperatures at least $2{ }^{\circ} \mathrm{C}$ warmer than present, and global sea level some $4-6 \mathrm{~m}$ higher than today ${ }^{49}$. Furthermore, the atmospheric $\mathrm{pCO}_{2}$ rise and warming of Antarctica was likely largely completed when Northern Hemisphere ice sheets started to melt ${ }^{48}$. These different boundary conditions surrounding TII lead to resolvable difference in our $\mathrm{Pb}$ and $\mathrm{Nd}$ isotopic records yet equally show striking similarities.

First of all, the changes in $\varepsilon_{\mathrm{Nd}}$ again followed changes seen in $\mathrm{Pb}$ isotopes with a delay of several thousand years. Analogously to Termination $\mathrm{I}, \mathrm{Pb}$ isotope compositions become more radiogenic during the penultimate deglaciation, yet after a short radiogenic spike at $132 \mathrm{ka}$ BP compositions quickly drop to intermediate values (Fig. 5k, l). In ${ }^{206} \mathrm{~Pb} /{ }^{204} \mathrm{~Pb}-{ }^{208} \mathrm{~Pb} /{ }^{206} \mathrm{~Pb}$ isotope space the deglacial changes follow a parallel trajectory to changes seen during TI, yet more closely resembling western Weddell Sea compositions (Fig. 3) as opposed to a trend toward eastern Weddell Sea compositions recorded during TI. The strong $\mathrm{Pb}$ isotopic similarities with western Weddell Sea compositions could be a consequence of increased melting of the West Antarctic Ice Sheet during $\mathrm{TII}^{50}$, yet this observation needs further investigation. The $\varepsilon_{\mathrm{Nd}}$ record shows similarly radiogenic compositions in the (de)glacial section preceding $133 \mathrm{ka} \mathrm{BP}$, followed by a less sharp switch to least radiogenic compositions coinciding with heaviest $\delta \mathrm{D}$ values seen in the Vostok ice core, followed by rather intermediate $\varepsilon_{\mathrm{Nd}}$ during MIS $5 \mathrm{e}$.

The Eemian interglacial was warmer than the Holocene and the Antarctic Ice Sheet likely smaller ${ }^{51}$. One study investigating the authigenic uranium concentration at ODP Site 1094, including opal flux and $\mathrm{Th}_{\mathrm{xs}}$ measurements, reported an apparent overturning stagnation event in the SO in the middle of the last interglacial $^{52}$ as a consequence of increased melting of Antarctic continental ice. Both our $\mathrm{Pb}$ and $\mathrm{Nd}$ isotopic compositions follow a well-defined perturbation alongside the authigenic uranium excursion (Fig. 5c, j), suggesting reduced Weddell Sea-derived AABW export within the Eemian. Our Eemian Nd isotope record never reaches a classical Holocene SO signature, which should be on the order of $\sim-8$, and is remarkably similar to the early deglacial Drake Passage cold-water coral record in $\mathrm{UCDW}^{45}$ during the reported interval. Whether this intermediate $\varepsilon_{\mathrm{Nd}}$ reflects the absence of Weddell Sea-derived AABW or is rather controlled by changes in SO overturning outside the Weddell Sea needs further research. Analogously to TI, however, the very radiogenic $\varepsilon_{\mathrm{Nd}}$ signature and unradiogenic $\mathrm{Pb}$ isotopic compositions observed preceding TII are observable and argue for the absence of Weddell Sea AABW export during the penultimate glacial maximum.

The lack of Weddell Sea AABW export into the Atlantic sector of the SO during the last two glacial maxima does not necessarily imply that this water mass was not formed, rather that it was too dense to be exported to our northern SO core sites. Such a scenario is not unlikely since a reduced Weddell Gyre circulation could lead to reduced diapycnal mixing within the basin. The Weddell Sea is bound by the South Scotia Ridge and the Bouvet Triple Junction to the North. While Weddell Sea Bottom Water is too dense to leave the Weddell Sea today, the admixture of 


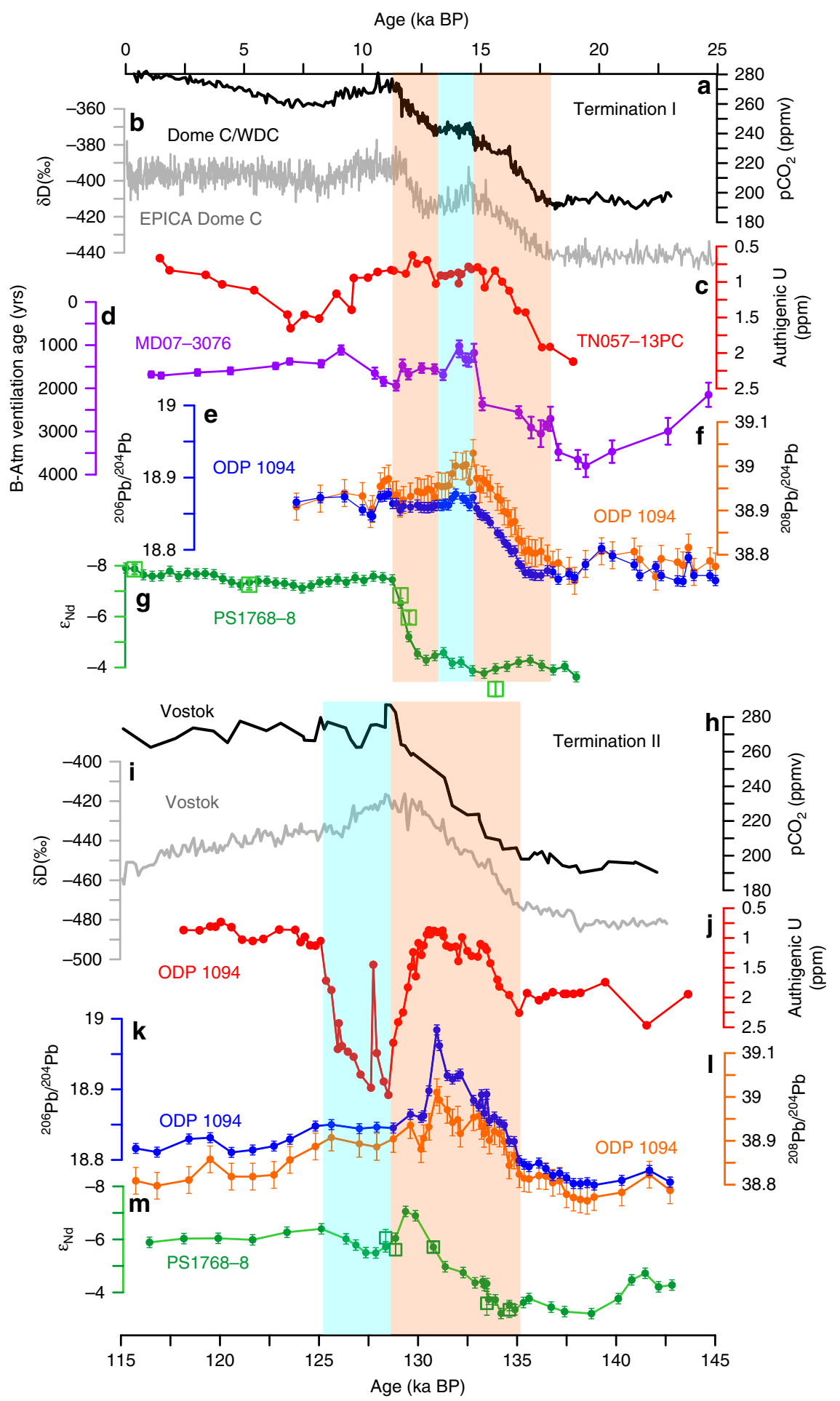

Fig. 5 Reconstructions covering Terminations I and II. a Atmospheric $\mathrm{pCO}_{2}$ concentrations from Antarctic Dome $\mathrm{C}$ ice core ${ }^{6}$ and the West Antarctic Ice Sheet Divide ice core $(W D C)^{11}$. b $\delta D^{74}$ from Dome $C$ and EPICA Dome $C$ ice cores. c Termination I sedimentary authigenic $U$ concentrations at Site TN057-13PC 4 . d Benthic-atmospheric (B-Atm) ventilation ages ${ }^{5}$. e, f ${ }^{206} \mathrm{~Pb} /{ }^{204} \mathrm{~Pb}$ and ${ }^{208} \mathrm{~Pb} /{ }^{204} \mathrm{~Pb}$ records in Termination I from ODP Site 1094. $\mathbf{g}$ Termination I $\varepsilon_{\mathrm{Nd}}$ records extracted from bulk sediment (closed green circles) and from opal (open green square) in core PS1768-8. h, i Atmospheric $\mathrm{pCO}_{2}{ }^{58}$ and $\delta D^{75}$ from Vostok ice core. j Termination II sedimentary authigenic $\mathrm{U}$ concentrations at ODP Site $1094^{52}$. k, I ${ }^{206} \mathrm{~Pb} /{ }^{204} \mathrm{~Pb}$ and ${ }^{208} \mathrm{~Pb} /{ }^{204} \mathrm{~Pb}$ records in Termination II from ODP Site 1094. $\mathbf{m}$ Termination II $\varepsilon_{\mathrm{Nd}}$ records extracted from bulk sediment (closed green circles) and from opal (open green square) in core PS1768-8. Error bars correspond to the $2 \sigma$ external error of the ${ }^{206} \mathrm{~Pb} /{ }^{204} \mathrm{~Pb},{ }^{208} \mathrm{~Pb} /{ }^{204} \mathrm{~Pb}$, and $\varepsilon_{\mathrm{Nd}}$ measurements. The orange and blue boxes higlight periods of strong and diminished deglacial atmospheric $\mathrm{pCO}_{2}$ rise. 
modified CDW within the Weddell Gyre is adding the required buoyancy to enable Weddell Sea AABW export ${ }^{53}$. Reduced Weddell Gyre circulation and associated lowered inflow of modified CDW, as well as extended sea ice coverage, may provide the boundary conditions required for the cessation of AABW export from the Weddell Sea. Given the bathymetry of the Weddell-Enderby abyssal plane we cannot exclude that a glacial equivalent of Weddell Sea AABW escaped the basin in deepest parts toward the east yet the northern export routes were closed. The clearly resolvable increase in atmospheric $\mathrm{pCO}_{2}$ late during TI and TII (Fig. 5) in turn illustrates how reinvigoration of Weddell Sea AABW ventilation contributed to partition carbon out of the ocean interior. As such, the resumption of AABW may have been instrumental in driving the deglacial sequence of events to completion.

\section{Methods}

Core positions. Ocean Drilling Program (ODP, Leg 177) Site $1094\left(53.2^{\circ} \mathrm{S}, 5.1^{\circ} \mathrm{E}\right.$, water depth $2807 \mathrm{~m}$ ) and RV Polarstern sediment core PS1768-8 $\left(53.6^{\circ} \mathrm{S}, 4.5^{\circ} \mathrm{E}\right.$, water depth $3299 \mathrm{~m}$ ) were retrieved from the Atlantic sector of the Southern Ocean, south of the modern Antarctic Polar Front (Fig. 1). Core PS1599-3 (74.1 ${ }^{\circ} \mathrm{S}$, $27.7^{\circ} \mathrm{W}$, water depth $2487 \mathrm{~m}$ ) was retrieved from the continental slope north of the Filchner-Rønne Ice Shelf (Fig. 1). Additional sediment core tops, collected from the sediment core repository of the Alfred Wegener Institute in Bremerhaven (Germany), used for seawater $\mathrm{Pb}$ isotopic characterization in Fig. 3 are listed in Supplementary Data 2.

Age model. For Termination I, existing age models of PS1599-3 $3^{54}$, PS1768-8 55 , and Site ODP $1094^{56}$ are directly taken from previous studies. For Termination II, the age model for Site ODP 1094 and PS1768-8 was refined via alignment of planktonic foraminiferal $\delta^{18} \mathrm{O}^{56,57}$ with Antarctic ice $\delta \mathrm{D}$ from Vostok ${ }^{58}$ assuming an in-phase relationship (Supplementary Fig. 2) as described in Jaccard et al. ${ }^{59}$.

$\mathrm{Pb}$ isotope measurements. The seawater $\mathrm{Pb}$ isotope signal was extracted from the authigenic Fe-Mn oxyhydroxide fraction of bulk sediment from ODP Site 1094 and 20 additional core-top bulk sediment samples following the leaching procedure refined from previous studies ${ }^{30,60}$. About $0.3 \mathrm{~g}$ of sediment samples were weighed and homogenized for each measurement. The authigenic Fe-Mn oxyhydroxide fraction in the sediment was extracted by vortexing the bulk sediment in a diluted reductive solution $(0.005 \mathrm{M}$ hydroxylamine hydrochloride/ $1.5 \%$ acetic acid/0.003 M Na-EDTA solution buffered to $\mathrm{pH} 4$ with $\mathrm{NaOH}$ ) on a vortex mixer not longer than $10 \mathrm{~s}$. The centrifuged trace metal solution was extracted and the $\mathrm{Pb}$ cuts purified by ion chromatography using AG1-X 8 resin $^{61}$. Our $\mathrm{Pb}$ isotope measurements were performed on a Thermo Scientific Neptune Plus MC-ICP-MS at GEOMAR, Kiel. Mass bias correction during $\mathrm{Pb}$ isotope measurements was done externally using the Tl-doping technique ${ }^{62,63}$ spiked by a NIST997 Tl standard solution ( $\mathrm{Pb}: \mathrm{Tl}=\sim 4: 1)$. Given that $\mathrm{Tl}$ and $\mathrm{Pb}$ fractionate slightly differently during ionization ${ }^{64},{ }^{205} \mathrm{Tl} / 203 \mathrm{Tl}$ were determined on a session-by-session basis so that NBS981 Pb isotope compositions matched published compositions ${ }^{63,65}$ (Supplementary Data 1$)$. Total procedural blanks were below $50 \mathrm{pg}(n=18)$ and are hence negligible. The reproducibility of the secondary standard USGS NOD-A-1 reproduced $\mathrm{Pb}$ isotope compositions with a precision of 0.007 for ${ }^{206} \mathrm{~Pb} /{ }^{204} \mathrm{~Pb}$ and 0.030 for ${ }^{208} \mathrm{~Pb} / 204 \mathrm{~Pb}(n=58)$.

Nd isotope measurements $\left(\varepsilon_{\mathbf{N d}}\right)$. The seawater $\mathrm{Nd}$ isotope signal was extracted from the Fe-Mn oxyhydroxide fraction of bulk sediment of PS1599-3 and PS17688 in an identical manner to our $\mathrm{Pb}$ leaching procedure. Eleven samples from core PS1768-8 were selected for the determination of the detrital sediment Nd isotope composition after preceding removal of the authigenic ferromanganese oxide phase $^{30}$. The Rare Earth Elements (REE) were separated from the leachate by cation exchange chromatography using $50 \mathrm{~W}$-X8 resin followed by separation of $\mathrm{Nd}$ from the other REE using LN-Spec resin 66,67 .

$\mathrm{Nd}$ isotope measurements were also performed on a Thermo Scientific Neptune Plus MC-ICP-MS at GEOMAR, Kiel. Instrumental mass fractionation was corrected by normalizing the measured ratio of ${ }^{143} \mathrm{Nd} /{ }^{144} \mathrm{Nd}$ to ${ }^{146} \mathrm{Nd} /{ }^{144} \mathrm{Nd}=$ 0.7219 using the mass bias correction procedure of Vance and Thirlwall ${ }^{64}$. The measured $\mathrm{Nd}$ isotope ratios were normalized to the published ${ }^{143} \mathrm{Nd} /{ }^{144} \mathrm{Nd}$ value of 0.512115 for JNdi- $1^{68}$. Total procedural blanks for $\mathrm{Nd}$ are below $30 \mathrm{pg}$ and hence negligible $(n=15)$. Secondary standard solution NIST 3135a reproduced within $0.20 \varepsilon_{\mathrm{Nd}}$ throughout the course of this study $(n=32)$ (Supplementary Data 3).

Our $\varepsilon_{\mathrm{Nd}}$ signal leached from surface sediment in core PS1768-8 is matching the actual seawater $\varepsilon_{\mathrm{Nd}} \operatorname{signal}^{32}$. Given the lack of foraminifera or fish teeth for comparison with the leachate $\mathrm{Nd}$ isotope data in the sediment, past seawater $\varepsilon_{\mathrm{Nd}}$ was also extracted from the $\mathrm{Fe}-\mathrm{Mn}$ oxyhydroxide fraction in nine separated biogenic opal samples picked from core PS1768-8 to confirm the validity of the leaching method. The fraction $>63 \mathrm{~mm}$ was dried and about $0.1 \mathrm{~g}$ of biogenic opal was picked. The authigenic Fe-Mn oxyhydroxide signal contained in the opal fraction was extracted by the same method we used for bulk sediment leaching. Our results obtained from the leachates of the $\mathrm{Fe}-\mathrm{Mn}$ oxyhydroxide fraction based on either bulk sediments or purified opal are in agreement and we can also exclude IRD control on the observed $\varepsilon_{\mathrm{Nd}}$ evolution (see Supplementary Discussion and Supplementary Figs. 3 and 4). Therefore, the $\varepsilon_{\mathrm{Nd}}$ evolution trend across the two terminations was reliably capturing a porewater signature ${ }^{29}$.

\section{Data availability}

Metadata and other results from the sediment cores are available within the Pangaea database (https://doi.org/10.1594/PANGAEA.909084).

Received: 15 April 2019; Accepted: 18 December 2019; Published online: 22 January 2020

\section{References}

1. Sigman, D. M. \& Boyle, E. A. Glacial/interglacial variations in atmospheric carbon dioxide. Nature 407, 859-869 (2000).

2. Anderson, R. F. et al. Wind-driven upwelling in the Southern Ocean and the deglacial rise in atmospheric $\mathrm{CO}_{2}$. Science 323, 1443-1448 (2009).

3. Burke, A. \& Robinson, L. F. The Southern Ocean's role in carbon exchange during the last deglaciation. Science 335, 557-561 (2012).

4. Jaccard, S. L., Galbraith, E. D., Martínez-García, A. \& Anderson, R. F. Covariation of deep Southern Ocean oxygenation and atmospheric $\mathrm{CO}_{2}$ through the last ice age. Nature 530, 207-210 (2016).

5. Skinner, L. C., Fallon, S., Waelbroeck, C., Michel, E. \& Barker, S. Ventilation of the deep Southern Ocean and deglacial $\mathrm{CO}_{2}$ rise. Science 328, 1147-1151 (2010).

6. Monnin, E. et al. Evidence for substantial accumulation rate variability in Antarctica during the Holocene, through synchronization of $\mathrm{CO}_{2}$ in the Taylor Dome, Dome C and DML ice cores. Earth Planet. Sci. Lett. 224, 45-54 (2004).

7. Shakun, J. D. et al. Global warming preceded by increasing carbon dioxide concentrations during the last deglaciation. Nature 484, 49-55 (2012).

8. Menviel, L. et al. Southern Hemisphere westerlies as a driver of the early deglacial atmospheric $\mathrm{CO}_{2}$ rise. Nat. Commun. 9, 2503 (2018).

9. Toggweiler, J. R. Variation of atmospheric $\mathrm{CO}_{2}$ by ventilation of the ocean's deepest water. Paleoceanography 14, 571-588 (1999).

10. Xiao, W., Esper, O. \& Gersonde, R. Last Glacial - Holocene climate variability in the Atlantic sector of the Southern Ocean. Quat. Sci. Rev. 135, 115-137 (2016).

11. Marcott, S. A. et al. Centennial-scale changes in the global carbon cycle during the last deglaciation. Nature 514, 616-619 (2014).

12. Hodell, D. A. \& Venz-Curtis, K. A. Late Neogene history of deepwater ventilation in the Southern Ocean. Geochem., Geophysics, Geosystems 7, Q09001 (2006).

13. Oppo, D. W. \& Lehman, S. J. Mid-depth circulation of the subpolar North Atlantic during the Last Glacial Maximum. Science 259, 1148-1152 (1993).

14. Adkins, J. F., McIntyre, K. \& Schrag, D. P. The salinity, temperature, and delta O-18 of the glacial deep ocean. Science 298, 1769-1773 (2002).

15. Skinner, L. C. Glacial-interglacial atmospheric $\mathrm{CO}_{2}$ change: a possible "standing volume" effect on deep-ocean carbon sequestration. Clim 5, 537-550 (2009).

16. Foldvik, A. et al. Ice shelf water overflow and bottom water formation in the southern Weddell Sea. J. Geophys. Res.: Oceans 109, C02015 (2004).

17. Huhn, O. et al. Evidence of deep- and bottom-water formation in the western Weddell Sea. Deep-Sea Res. Part Ii-Topical Stud. Oceanogr. 55, 1098-1116 (2008).

18. Orsi, A. H., Johnson, G. C. \& Bullister, J. L. Circulation, mixing, and production of Antarctic Bottom Water. Prog. Oceanogr. 43, 55-109 (1999).

19. Kerr, R., Dotto, T. S., Mata, M. M. \& Hellmer, H. H. Three decades of deep water mass investigation in the Weddell Sea (1984-2014): temporal variability and changes. Deep Sea Res. Part II: Topical Stud. Oceanogr. 149, 70-83 (2018).

20. Naveira Garabato, A. C., McDonagh, E. L., Stevens, D. P., Heywood, K. J. \& Sanders, R. J. On the export of Antarctic Bottom Water from the Weddell Sea. Deep Sea Res. Part II: Topical Stud. Oceanogr. 49, 4715-4742 (2002)

21. Purkey, S. G. et al. A synoptic view of the ventilation and circulation of Antarctic Bottom Water from chlorofluorocarbons and natural tracers. Annu. Rev. Mar. Sci. 10, 503-527 (2018).

22. Naveira Garabato, A. C., Heywood, K. J. \& Stevens, D. P. Modification and pathways of Southern Ocean Deep Waters in the Scotia Sea. Deep Sea Res. Part I: Oceanographic Res. Pap. 49, 681-705 (2002).

23. Frank, M. Radiogenic isotopes: Tracers of past ocean circulation and erosional input. Rev. Geophys 40, Art. No.: 1001 (2002). 
24. Abbott, A. N., Haley, B. A. \& McManus, J. Bottoms up: sedimentary control of the deep North Pacific Ocean's $\varepsilon_{\mathrm{Nd}}$ signature. Geology 43, 1035-1035 (2015).

25. Henderson, G. M. \& Maier-Reimer, E. Advection and removal of $210 \mathrm{~Pb}$ and stable $\mathrm{Pb}$ isotopes in the oceans: a general circulation model study. Geochimica et. Cosmochimica Acta 66, 257-272 (2002).

26. Tachikawa, K., Athias, V. \& Jeandel, C. Neodymium budget in the modern ocean and paleo-oceanographic implications. J. Geophys. Res.-Oceans 108, Art. No. 3254 (2003).

27. Wu, J., Rember, R., Jin, M., Boyle, E. A. \& Flegal, A. R. Isotopic evidence for the source of lead in the North Pacific abyssal water. Geochimica et. Cosmochimica Acta 74, 4629-4638 (2010).

28. Du, J. H., Haley, B. A. \& Mix, A. C. Neodymium isotopes in authigenic phases, bottom waters and detrital sediments in the Gulf of Alaska and their implications for paleo-circulation reconstruction. Geochimica Et. Cosmochimica Acta 193, 14-35 (2016).

29. Blaser, P. et al. The resilience and sensitivity of Northeast Atlantic deep water $\varepsilon N d$ to overprinting by detrital fluxes over the past 30,000 years. Geochimica et. Cosmochimica Acta 245, 79-97 (2019).

30. Gutjahr, M. et al. Reliable extraction of a deepwater trace metal isotope signal from $\mathrm{Fe}-\mathrm{Mn}$ oxyhydroxide coatings of marine sediments. Chem. Geol. 242, 351-370 (2007).

31. Watson, A. J. \& Garabato, A. C. N. The role of Southern Ocean mixing and upwelling in glacial-interglacial atmospheric CO2 change. Tellus Ser. B-Chem. Phys. Meteorol. 58, 73-87 (2006).

32. Stichel, T., Frank, M., Rickli, J. \& Haley, B. A. The hafnium and neodymium isotope composition of seawater in the Atlantic sector of the Southern Ocean. Earth Planet. Sci. Lett. 317-318, 282-294 (2012).

33. Buizert, C. et al. Abrupt ice-age shifts in southern westerly winds and Antarctic climate forced from the north. Nature 563, 681-685 (2018).

34. Basak, C. et al. Breakup of last glacial deep stratification in the South Pacific. Science 359, 900-904 (2018).

35. Sikes, E. L., Allen, K. A. \& Lund, D. C. Enhanced $\delta^{13} \mathrm{C}$ and $\delta^{18} \mathrm{O}$ differences between the South Atlantic and South Pacific during the last glaciation: the deep gateway hypothesis. Paleoceanography 32, 1000-1017 (2017).

36. Weber, M. E. et al. Millennial-scale variability in Antarctic ice-sheet discharge during the last deglaciation. Nature 510, 134-138 (2014).

37. Golledge, N. R. et al. Antarctic contribution to meltwater pulse 1A from reduced Southern Ocean overturning. Nat. Commun. 5, 5107 (2014).

38. Piotrowski, A. M., Goldstein, S. L., Hemming, S. R. \& Fairbanks, R. G. Intensification and variability of ocean thermohaline circulation through the last deglaciation. Earth Planet. Sci. Lett. 225, 205-220 (2004).

39. Lippold, J. et al. Deep water provenance and dynamics of the (de)glacial Atlantic meridional overturning circulation. Earth Planet. Sci. Lett. 445, 68-78 (2016).

40. Adkins, J. F. The role of deep ocean circulation in setting glacial climates. Paleoceanography 28, 539-561 (2013).

41. Rae, J. W. B. et al. $\mathrm{CO}_{2}$ storage and release in the deep Southern Ocean on millennial to centennial timescales. Nature 562, 569-573 (2018).

42. Smith, J. A., Hillenbrand, C.-D., Pudsey, C. J., Allen, C. S. \& Graham, A. G. C. The presence of polynyas in the Weddell Sea during the Last Glacial Period with implications for the reconstruction of sea-ice limits and ice sheet history. Earth Planet. Sci. Lett. 296, 287-298 (2010).

43. Fröllje, H. et al. Hawaiian imprint on dissolved $\mathrm{Nd}$ and $\mathrm{Ra}$ isotopes and rare earth elements in the central North Pacific: Local survey and seasonal variability. Geochimica et. Cosmochimica Acta 189, 110-131 (2016).

44. Kawabe, M. \& Fujio, S. Pacific ocean circulation based on observation. J. Oceanogr. 66, 389-403 (2010).

45. Struve, T. in Earth Science \& Engineering (Imperial College London, 2015).

46. Skinner, L. C. et al. North Atlantic versus Southern Ocean contributions to a deglacial surge in deep ocean ventilation. Geology 41, 667-670 (2013).

47. Berger, A. \& Loutre, M. F. Insolation values for the climate of the last 10000000 years. Quat. Sci. Rev. 10, 297-317 (1991).

48. Broecker, W. S. \& Henderson, G. M. The sequence of events surrounding Termination II and their implications for the cause of glacial-interglacial $\mathrm{CO}_{2}$ changes. Paleoceanography 13, 352-364 (1998).

49. Rohling, E. J. et al. High rates of sea-level rise during the last interglacial period. Nat. Geosci. 1, 38 (2007)

50. Sutter, J., Gierz, P., Grosfeld, K., Thoma, M. \& Lohmann, G. Ocean temperature thresholds for Last Interglacial West Antarctic Ice Sheet collapse. Geophys. Res. Lett. 43, 2675-2682 (2016).

51. Huybrechts, P. Sea-level changes at the LGM from ice-dynamic reconstructions of the Greenland and Antarctic ice sheets during the glacial cycles. Quat. Sci. Rev. 21, 203-231 (2002).

52. Hayes, C. T. et al. A stagnation event in the deep South Atlantic during the last interglacial period. Science 346, 1514-1517 (2014).

53. Huhn, O., Rhein, M., Hoppema, M. \& van Heuven, S. Decline of deep and bottom water ventilation and slowing down of anthropogenic carbon storage in the Weddell Sea, 1984-2011. Deep-Sea Res Pt I 76, 66-84 (2013).
54. Weber, M. E. et al. Interhemispheric ice-sheet synchronicity during the last glacial maximum. Science 334, 1265-1269 (2011).

55. Frank, M., Mangini, A., Gersonde, R., Rutgers van der Loeff, M. \& Kuhn, G. Late Quaternary sediment dating and quantification of lateral sediment redistribution applying ${ }^{230} \mathrm{Th}_{\text {ex }}$ : a study from the eastern Atlantic sector of the Southern Ocean. Geologische Rundsch. 85, 554-566 (1996).

56. Hodell, D. A. et al. Stable isotope record of benthic and planktonic foraminifera in sediment cores of ODP Leg 177, Southern Ocean. in Proceedings of the Ocean Drilling Program, Scientific Results, College Station, TX (Ocean Drilling Program) 177, 1-26 (2003).

57. Niebler, H.-S. Stable isotope record of foraminifera from South Atlantic sediments with reconstruction of paleotemperatures and paleosalinities. Pangaea https://doi.org/10.1594/PANGAEA.835327 (1995).

58. Petit, J. R. et al. Climate and atmospheric history of the past 420,000 years from the Vostok ice core, Antarctica. Nature 399, 429-436 (1999).

59. Jaccard, S. L. et al. Two modes of change in Southern Ocean productivity over the past million years. Science 339, 1419-1423 (2013).

60. Blaser, P. et al. Extracting foraminiferal seawater Nd isotope signatures from bulk deep sea sediment by chemical leaching. Chem. Geol. 439, 189-204 (2016).

61. Lugmair, G. W. \& Galer, S. J. G. Age and isotopic relationships among the angrites Lewis Cliff 86010 and Angra dos Reis. Geochimica et. Cosmochimica Acta 56, 1673-1694 (1992).

62. Thirlwall, M. F. Multicollector ICP-MS analysis of $\mathrm{Pb}$ isotopes using a $207 \mathrm{~Pb}-204 \mathrm{~Pb}$ double spike demonstrates up to $400 \mathrm{ppm} / \mathrm{amu}$ systematic errors in Tl-normalization. Chem. Geol. 184, 255-279 (2002).

63. Süfke, F. et al. Early stage weathering systematics of $\mathrm{Pb}$ and $\mathrm{Nd}$ isotopes derived from a high-Alpine Holocene lake sediment record. Chem. Geol. 507, 42-53 (2019)

64. Vance, D. \& Thirlwall, M. An assessment of mass discrimination in MCICPMS using Nd isotopes. Chem. Geol. 185, 227-240 (2002).

65. Baker, J., Peate, D., Waight, T. \& Meyzen, C. Pb isotopic analysis of standards and samples using a $207 \mathrm{~Pb}-204 \mathrm{~Pb}$ double spike and thallium to correct for mass bias with a double-focusing MC-ICP-MS. Chem. Geol. 211, 275-303 (2004).

66. Carsten, M., Stefan, W., Erik, S. \& Klaus, M. Separation of high field strength elements (Nb, Ta, Zr, Hf) and Lu from rock samples for MC-ICPMS measurements. Geochem., Geophysics, Geosystems 2, 1064 (2001).

67. Pin, C. \& Zalduegui, J. S. Sequential separation of light rare-earth elements, thorium and uranium by miniaturized extraction chromatography: application to isotopic analyses of silicate rocks. Analytica Chim. Acta 339, 79-89 (1997)

68. Tanaka, T. et al. JNdi-1: a neodymium isotopic reference in consistency with LaJolla neodymium. Chem. Geol. 168, 279-281 (2000).

69. Garcia, H. E. et al. Dissolved oxygen, apparent oxygen utilization, and oxygen saturation. World Ocean Atlas 2013 3, 27 (2013).

70. Zweng, M. M. et al. Salinity. World Ocean Atlas 2013 2, 39 (2013).

71. Schlitzer, R. Ocean Data View http://odv.awi.de (2011).

72. Abouchami, W. \& Goldstein, S. L. A lead isotopic study of circum-antarctic manganese nodules. Geochimica et. Cosmochimica Acta 59, 1809-1820 (1995).

73. Hellmer, H. H. et al. Meteorology and oceanography of the Atlantic sector of the Southern Ocean-a review of German achievements from the last decade. Ocean Dyn. 66, 1379-1413 (2016).

74. Parrenin, F. et al. Synchronous change of atmospheric $\mathrm{CO}_{2}$ and Antarctic temperature during the last deglacial warming. Science 339, 1060-1063 (2013).

75. Waelbroeck, C. et al. A comparison of the Vostok ice deuterium record and series from Southern Ocean core MD 88-770 over the last two glacialinterglacial cycles. Clim. Dyn. 12, 113-123 (1995).

\section{Acknowledgements}

Sediment material for this study was obtained from the AWI core repository in Bremerhaven and the ODP/IODP core repository Bremen. We thank T. Goepfert, A. Kolevica, and M. Seebeck for technical support. This paper benefited from discussions with S. Jaccard, M. Frank, and J. Lippold. H. Huang acknowledges the China Scholarship Council (CSC) for providing financial support to his overseas study.

\section{Author contributions}

M.G. conceived the study and initialized this project in cooperation with G.K. M.G., H.H and G.K. selected the core sites and provided geochemical data. H.H. carried out the analytical work as well as the $\mathrm{Pb}$ and $\mathrm{Nd}$ isotopic analyses with guidance from M.G. and A.E. H.H. and M.G. wrote the paper. All coauthors contributed to the final version.

\section{Competing interests}

The authors declare no competing interests. 


\section{Additional information}

Supplementary information is available for this paper at https://doi.org/10.1038/s41467 020-14302-3.

Correspondence and requests for materials should be addressed to H.H.

Peer review information Nature Communications thanks the anonymous reviewer(s) for their contribution to the peer review of this work. Peer reviewer reports are available.

Reprints and permission information is available at http://www.nature.com/reprints

Publisher's note Springer Nature remains neutral with regard to jurisdictional claims in published maps and institutional affiliations. (c) Open Access This article is licensed under a Creative Commons Attribution 4.0 International License, which permits use, sharing, adaptation, distribution and reproduction in any medium or format, as long as you give appropriate credit to the original author(s) and the source, provide a link to the Creative Commons license, and indicate if changes were made. The images or other third party material in this article are included in the article's Creative Commons license, unless indicated otherwise in a credit line to the material. If material is not included in the article's Creative Commons license and your intended use is not permitted by statutory regulation or exceeds the permitted use, you will need to obtain permission directly from the copyright holder. To view a copy of this license, visit http://creativecommons.org/licenses/by/4.0/.

(C) The Author(s) 2020 